\title{
Supplementation levels for non-lactating cows grazing during the rainy season
}

\section{Níveis de suplementação em vacas não-lactantes em pastejo no período das águas}

\author{
Joelson Antonio Silva ${ }^{1 *}$; Luciano da Silva $\mathrm{Cabral}^{2}$; Daniel de Paula Sousa ${ }^{2}$; \\ André Soares de Oliveira ${ }^{2}$; Rosemary Lais Galati²; Marcelo Diniz dos Santos ${ }^{3}$; \\ Nelcino Francisco de Paula²; Camilla Gabriela Miranda Silva ${ }^{4}$; \\ Wagner Soares da Costa Júnior ${ }^{4}$; Isis Scatolin de Oliveira ${ }^{5}$
}

\begin{abstract}
This study aimed to evaluate levels of concentrate supplementation $\left(1.5,3.0,4.5\right.$ and $\left.6.0 \mathrm{~kg} \mathrm{day}^{-1}\right)$ for grazing dairy cows kept on Panicum maximum Jacq. cv. Tanzania pasture during the rainy season on nutrient intake and digestibility and rumen parameters. Four rumen cannulated non-lactating Holstein $\times$ Zebu crossbred cows were used in this study by a $4 \mathrm{X} 4$ Latin square design, which presented an average initial body weight of $521.69 \pm 31.98 \mathrm{~kg}$. Each period lasted 17 days, being the first 10 days were used for animal adaptation and the remaining seven days for data collection. There was no effect $(\mathrm{P}>0.05)$ of supplementation levels on total dry matter intake, although forage dry matter intake has been linearly decreased $(\mathrm{P}<0.05)$. Treatments have no effect $(\mathrm{P}>0.05)$ on the digestibility coefficients of dry matter, organic matter, crude protein, or ether extract. There was a linear increase $(\mathrm{P}<0.05)$ on daily rumination time and total rumination times according to supplementation levels. There was no significant effect of supplementation levels $(\mathrm{P}>0.05)$ or time after supplementation on rumen $\mathrm{pH}$. Rumen ammonia nitrogen concentration responded quadratically $(\mathrm{P}<0.05)$ to times after supplementation, with a maximum estimated concentration of $17.61 \mathrm{mg} \mathrm{dL}^{-1}$ at $3.87 \mathrm{~h}$ after supplementation. Increasing supplementation levels for grazing dairy cows reduces forage intake but has no negative effects on total dry matter intake or rumen-fluid $\mathrm{pH}$.
\end{abstract}

Key words: Concentrate. Herbage intake. Rumen parameters.

\section{Resumo}

Objetivou-se avaliar o efeito de níveis de suplementação concentrada $\left(1,5 ; 3,0 ; 4,5\right.$ e $\left.6,0 \mathrm{~kg} \mathrm{dia}^{-1}\right)$ em vacas leiteiras mantidas em pasto de Panicum maximum Jacq. cv. Tanzânia no período das águas, sobre o consumo e a digestibilidade dos nutrientes e parâmetros ruminais. Foram utilizadas quatro vacas

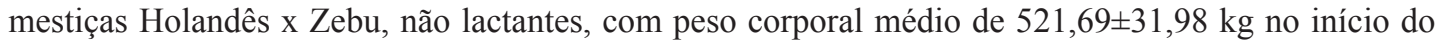
experimento distribuídas aleatoriamente em delineamento em quadrado latino $4 \mathrm{X} 4$. Cada período teve

${ }^{1}$ Discente de Doutorado do Programa de Pós-Graduação em Ciência Animal, Universidade Federal de Mato Grosso, UFMT, Cuiabá, MT, Brasil. E-mail: joelson.silva@hotmail.com

2 Profs. Drs., Programa de Pós-Graduação em Ciência Animal, UFMT, Cuiabá, MT, Brasil. E-mail: lucianoufmt@gmail.com; depaulasousa@gmail.com; andresoli@uol.com.br; galatirosemarylais@gmail.com; nelcinodepaula@hotmail.com

3 Prof., Pós-Doutor do Programa de Pós-Graduação em Biociência Animal, Universidade de Cuiabá, UNIC, Cuiabá, MT, Brasil. E-mail: smarcelodiniz@gmail.com

${ }^{4}$ Discente de Mestrado do Programa de Pós-Graduação em Ciência Animal, UFMT, Cuiabá, MT, Brasil. E-mail: milla_miranda@ hotmail.com; wjr_zootecnia@hotmail.com

${ }^{5}$ Prof $^{\mathrm{a}} \mathrm{Dr}^{\mathrm{a}}$, Departamento de Zootecnia e Extensão Rural, UFMT, Cuiabá, MT, Brasil. E-mail: isisscatolin@hotmail.com

* Author for correspondence 
duração de 17 dias, sendo os 10 dias iniciais para adaptação dos animais aos tratamentos e os sete dias restantes para coletas de dados. Não houve efeito $(P>0,05)$ dos níveis de suplementação sobre o consumo de matéria seca total com redução linear $(\mathrm{P}<0,05)$ no consumo de matéria seca de forragem. Não houve efeito $(\mathrm{P}>0,05)$ dos tratamentos nos coeficientes de digestibilidade da matéria seca, matéria orgânica, proteína bruta e extrato etéreo. Houve aumento linear $(\mathrm{P}<0,05)$ do tempo de ruminação diurna e total com o aumento dos níveis de suplementação. Não houve efeito significativo dos níveis de suplementação $(\mathrm{P}>0,05)$ e tempo após a suplementação sobre o $\mathrm{pH}$ ruminal. A concentração de nitrogênio amoniacal ruminal apresentou comportamento quadrático $(\mathrm{P}<0,05)$ em relação aos tempos após a alimentação, sendo estimado valor máximo de $17,61 \mathrm{mg} \mathrm{dL}^{-1}$ no tempo 3,87 horas após a alimentação. $\mathrm{O}$ aumento dos níveis de suplementação para vacas leiteiras mantidas a pasto reduz o consumo de forragem, sem afetar negativamente o consumo de matéria seca total e sem alterar os valores de $\mathrm{pH}$ do líquido ruminal.

Palavras-chave: Concentrado. Consumo de forragem. Parâmetros ruminais.

\section{Introduction}

The use of pastures in the feeding of dairy cows generates a low-cost production system, since the pasture is the cheapest of roughage feedstuffs for ruminants (BARGO et al., 2002). However, according to Santos et al. (2003), exclusive use of grasses may not fully meet the nutritional requirements of animals.

Therefore, the use of concentrate supplements represents the main strategy to increase the milk yield of dairy cows reared on pasture. Exclusive use of concentrate supplements may, however, lead to expressive changes in the rumen environment, which may include a decline in $\mathrm{pH}$, passage rate of solids and fluids, and volume of secreted saliva; alterations in the growth of microorganism species and microbial groups; and alterations in nutrient digestion (protein, fiber, etc.).

Amidst these changes, in general, variations in the rumen $\mathrm{pH}$ are more frequent, because concentrate feeds have a high rate of rumen digestion, and the end products of their fermentation, when in excess, may reduce the rumen $\mathrm{pH}$ and compromise the fiber digestion and the animal's health (ØRSKOV, 1986). According to this researcher, the rumen $\mathrm{pH}$ may range from 6.2 to 7.0 when animals are fed roughage-only diets, but it may be lower than 5.5 when diets containing over $70 \%$ concentrate are used.
As stated by González et al. (2012), the maintenance of the rumen $\mathrm{pH}$ depends on buffering events, including the action of saliva, which has a high buffer capacity and contributes with approximately $30 \%$ of the total buffering of volatile fatty acids in the rumen; the absorptive capacity of the rumen epithelium, which neutralizes around $50 \%$ of volatile fatty acids in the rumen; the action of lactate-using bacteria (Megasphaera elsdenii and Selenomonas ruminantium); and the passage of volatile fatty acids from the rumen to the other compartments of the gastrointestinal tract. For these reasons, the importance of evaluating parameters associated with digestion and fermentation of feeds must be stressed.

The aim of this study was to evaluate the intakes of total dry matter, herbage dry matter, and nutrients; digestibility; feeding behavior; and nutritional parameters of non-lactating dairy cows supplemented with increasing levels of concentrate, grazing on a Tanzania grass pasture.

\section{Material and Methods}

The experiment was conducted at the Milk Production and Processing Unit of the Experimental Farm at the Federal University of Mato Grosso, located in the municipality of Santo Antônio do Leverger, MT, Brazil, between December and March. 
Four rumen-cannulated, non-lactating Holstein $\times$ Zebu crossbred cows with an average body weight of $521.69 \pm 31.98 \mathrm{~kg}$ were distributed in a $4 \times 4$ Latin square. The experiment consisted of four experimental periods, each lasting 17 days, the first 10 of which were used for the adaptation of animals to the diets and the remaining seven for data collection.
Treatments consisted of four supplementation levels $\left(1.5,3.0,4.5\right.$, and $6.0 \mathrm{~kg} \mathrm{day}^{-1}$, corresponding to $0.29,0.57,0.86$, and $1.17 \%$ body weight day $^{-1}$ ). Supplements were formulated based on the composition of commercial supplements for dairy cows used in the region (Table 1); they were provided twice daily, in equal amounts, in the morning (06h30) and in the afternoon (15h30). Possible leftovers were weighed to determine individual intake.

Table 1. Centesimal composition of supplement ingredients.

\begin{tabular}{lc}
\hline \multicolumn{1}{c}{ Ingredient } & $\%$ \\
\hline Ground corn & 48.5 \\
Soybean meal & 26.0 \\
Sunflower cake & 20.0 \\
Urea & 1.0 \\
Mineral-vitamin mixture $^{1}$ & 4.5 \\
\hline
\end{tabular}

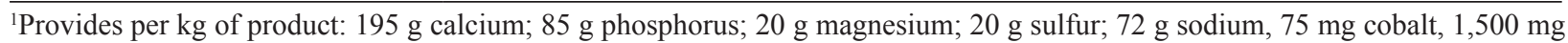
copper; $65 \mathrm{mg}$ iodine, $27 \mathrm{~g}$ selenium, 1,800 mg manganese; 4,500 mg zinc; $130,000 \mathrm{IU} \mathrm{kg}^{-1}$ vitamin A; $12,000 \mathrm{IU} \mathrm{kg}^{-1}$ vitamin D; $1,000 \mathrm{IU} \mathrm{kg}^{-1}$ vitamin E, $850 \mathrm{mg}$ (maximum) fluorine. ${ }^{2}$ Neutral detergent insoluble fiber corrected for ash and protein.

Cows were kept in a single lot in the experimental unit, which consisted of 10 Panicum maximum Jacq. cv. Tanzania paddocks measuring 2,500 $\mathrm{m}^{2}$, managed in a rotational grazing system. During the experiment, the average length of occupation of each paddock was 1.04 days, with 11.2 days of rest, under a stocking rate of $6.3 \mathrm{AU}^{-1}$. The pasture was managed based on the pasture entry height of $70 \mathrm{~cm}$, corresponding to $95 \%$ light interception (CARNEVALLI et al., 2006) and expected exit at 40 and $50 \mathrm{~cm}$ in height. Throughout the experimental period, the pasture was fertilized with $88 \mathrm{~kg}$ nitrogen and $88 \mathrm{~kg}$ potassium per hectare.

Data pertaining to climatic conditions were obtained from the meteorological station at the Federal University of Mato Grosso (UFMT). Average temperature was $27.54{ }^{\circ} \mathrm{C}$; average air relative humidity was $74.20 \%$; and accumulated precipitation in the period was $404.5 \mathrm{~mm}$.

The pre- and post-grazing herbage mass was determined by measuring 20 points in the paddock and sampling it with a $0.5 \times 0.5 \mathrm{~m}$ square at the average height of each paddock (cut near the soil level) on the 5th, 10th, and 14th days of each experimental period. Two aliquots were homogenized and collected: one to determine the herbage mass $(\mathrm{kg}$ $\mathrm{DM} \mathrm{ha}^{-1}$ ) and another for fractionation and analysis of the availability of DM from green and dry leaf (leaf blades) and green and dry stem (stem + sheath) per hectare in each experimental paddock.

The pasture consumed by the animals was sampled via manual grazing simulation. Collections were performed by a single sampler on the 10th and 12 th days of each experimental period. Concentrate ingredients and the concentrate itself were sampled when the ingredients were mixed.

Herbage intake was estimated by using an internal and an external marker. First, fecal excretion was obtained using the external marker chromium oxide (15 g), which was provided individually in paper bags between the 4th and 11th days of each experimental period. Samples of feces $(200 \mathrm{~g})$ were 
collected directly from the rectum between the 10th and 12th days of the period, according to the following distribution: 10th day (17h00), 11th day (11h00), and 12th day (06h00).

Herbage intake was estimated using the internal marker indigestible neutral detergent insoluble fiber (iNDF), following Detmann et al. (2001).

The feeding behavior of the animals was evaluated on the 15th day of the experimental period, by monitoring them over $24 \mathrm{~h}$. Grazing, rumination, and idle behaviors were observed at every five minutes. The time expended on the selection or capture of herbage, including the short period used to move and select the herbage, was counted as grazing time. The rest time was considered as an idle activity, and rumination was considered when animals ceased their grazing activity and started chewing.

Samples of herbage, ingredients, leftovers, and feces were pre-dried in forced-air ovens at $60 \pm 5{ }^{\circ} \mathrm{C}$ for $72 \mathrm{~h}$ and ground through $1-\mathrm{mm}$ sieves for analyses of the dry matter (DM), organic matter (OM), mineral matter (MM), crude protein (CP), and ether extract (EE) contents, following AOAC (1990). The neutral (NDF) and acid (ADF) detergent insoluble fiber contents were obtained according to Van Soest et al. (1991). Neutral detergent insoluble nitrogen (NDIN) contents were obtained from the residue (NDF) after the soluble contents were extracted from the samples in neutral detergent (VAN SOEST et al., 1991), via the procedure described by Kjeldahl (AOAC, 1990); the NDF contents were corrected for ash and protein (NDFap) (Table 2).

Table 2. Chemical composition of supplement and Tanzania grass.

\begin{tabular}{lcc}
\hline \multicolumn{1}{c}{ Composition, \% DM } & Supplement & Tanzania \\
\hline Dry matter & 81.32 & 27.30 \\
Mineral matter & 7.61 & 7.59 \\
Organic matter & 92.39 & 92.41 \\
Crude protein & 23.17 & 15.49 \\
Ether extract & 3.80 & 4.35 \\
Neutral detergent insoluble fiber & 13.39 & 68.12 \\
Acid detergent insoluble fiber & 12.48 & 23.63 \\
NDFap & 12.00 & 59.08 \\
Non-fibrous carbohydrates & 46.42 & 12.24 \\
Indigestible neutral detergent insoluble fiber & 7.82 & 10.64 \\
Neutral detergent insoluble nitrogen (\% of total N) & 4.29 & 44.32 \\
\hline
\end{tabular}

${ }^{1}$ NDFap $=$ neutral detergent insoluble fiber corrected for ash and protein.

Because of the presence of urea in the diets, NFC were calculated according to Hall (2000): NFC = $100-[(\% \mathrm{CP}-\% \mathrm{CP}$ from urea $+\%$ urea $)+\%$ NDFap $+\% \mathrm{EE}+\% \mathrm{ash}$. Total digestible nutrients (TDN) were calculated following NRC (2001): TDN = $\mathrm{DCP}+\mathrm{DNFC}+\mathrm{DNDFap}+\mathrm{DEE} \times 2.25$, where DCP: digestible crude protein; DNFC: digestible non-fibrous carbohydrates; DNDFap: digestible neutral detergent insoluble fiber corrected for ash and protein; and DEE: digestible ether extract.
On the 16th day of each experimental period, rumen fluid was collected before ( 0 ) and $2,4,6$, and $8 \mathrm{~h}$ after the beginning of the morning feeding to determine the $\mathrm{pH}$ and the ammonia concentration. The $\mathrm{pH}$ was determined immediately using a digital $\mathrm{pH}$ meter, and a $50-\mathrm{mL}$ aliquot was obtained for

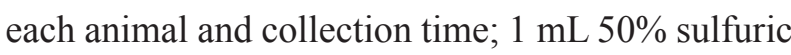
acid was added to the sample, which was stored in a freezer at $-20{ }^{\circ} \mathrm{C}$. Later, the rumen ammonia nitrogen (RAN) concentration was determined. 
The evaluated variables were analyzed as a $4 \times$ 4 Latin square using the MIXED procedure of SAS version 9.3 (SAS, 2011). The model included the fixed effect (level of supplement supply) and the random effects (animal, period, and residual height). The LSMEANS option was used to generate the individual means for each supplementation level. Orthogonal contrasts were used for the specific partition of the effects of treatment into linear, quadratic, and cubic. Because of the lack of cubic effects, these were omitted from the table.

The $\mathrm{pH}$ and the concentrations of ammonia nitrogen were analyzed as repeated measures over time using the MIXED procedure of SAS version 9.3 (SAS, 2011). The model included supplementation level, collection time, and supplementation level $\times$ collection time interaction as fixed effects, and animal, period, and residual height as random effects. $\mathrm{pH}$ and initial ammonia nitrogen values were used as co-variables in the models. For the analysis of variables, structures of covariance matrix of the errors were adjusted. Of all structures investigated, ARH (1) (first-order heterogeneous autoregressive) was the most suitable according to the Bayesian information criterion (BIC). Degrees of freedom and tests were adjusted using the Kenward-Roger option. The LSMEANS option was used to generate the individual means for each supplementation level and for the collection times. The same aforementioned contrasts were used for the partition of treatment effects. For all procedures, effects were considered significant at $\mathrm{P}<0.05$.

\section{Results and Discussion}

The average pre- and post-grazing Tanzania grass heights were 83.28 and $54.22 \mathrm{~cm}$, respectively, corresponding to an average herbage mass of 8.24 and 5.29 $\mathrm{tha}^{-1} \mathrm{DM}$, respectively (Table 3). Based on these values, an herbage DM availability of $154 \mathrm{~kg}$ per animal day ${ }^{-1}$ was estimated.

Table 3. Herbage mass and average structural characteristics of Tanzania grass pasture.

\begin{tabular}{lcc}
\hline \multicolumn{1}{c}{ Parameter } & Pre-grazing & Post-grazing \\
\hline Height, cm & 83.28 & 54.22 \\
Herbage mass, t ha $^{-1}$ DM & 8.24 & 5.29 \\
Green leaf, \% DM & 46.90 & 35.16 \\
Dry leaf, \% DM & 2.09 & 1.95 \\
Green stem, \% DM & 48.24 & 60.39 \\
Dry stem, \% DM & 2.78 & 2.50 \\
L:S ratio & 0.97 & 0.58 \\
\hline
\end{tabular}

${ }^{1}$ Green leaf:green stem ratio. DM $=$ Dry matter.

At pre-grazing, the average pasture height was above the range of 70 to $75 \mathrm{~cm}$, corresponding to 95\% light interception (LI) for the Tanzania grass, as remarked byBarbosa et al. (2006), Carnevalli et al. (2006), and Zanine et al. (2011). According to these authors, at up to $95 \% \mathrm{LI}$, the leaf area is larger and leaf growth rates are higher. However, after this point, stems elongate and senescent material accumulates in the pasture, affecting the herbage growth efficiency, the pasture structure, and its nutritional value.
A lower proportion of green leaf $(46.90 \%)$ was observed as compared with the findings of Difante et al. (2010) (59.6\%), who kept the Tanzania grass managed at $95 \%$ LI pre-grazing, corresponding to a pasture height of $68.4 \mathrm{~cm}$, which likely contributed to a greater proportion of leaves. The average post-grazing pasture height of $54.33 \mathrm{~cm}$ in our study was higher than the 25 and $30 \mathrm{~cm}$ recommended by Barbosa et al. (2006) and Zanine et al. (2011), respectively, which contributed to the elongation of stems and their high participation $(48.24 \%)$ in the pasture. 
Average concentrate intake was 1.30, 2.42, 2.94, and $2.95 \mathrm{~kg} \mathrm{DM} \mathrm{day}{ }^{-1}$, corresponding to $0.25,0.46,0.56$, and $0.57 \%$ of the average body weight day ${ }^{-1}$ (Table 4). These values were lower than the supplementation levels established for the experiment $\left(1.5,3.0,4.5\right.$, and $\left.6.0 \mathrm{~kg} \mathrm{day}^{-1}\right)$, probably because this study involved non-lactating, rumenfistulated cows, which have a lower nutritional requirement than lactating cows, and because of the high quality and availability of the herbage (Tables 1 and 2).

Table 4. Total dry matter intake, herbage dry matter intake, and nutrients according to supplementation level.

\begin{tabular}{|c|c|c|c|c|c|c|c|}
\hline \multirow{2}{*}{ Item $^{1}$} & \multicolumn{4}{|c|}{ Supplementation level $\left(\mathrm{kg} \mathrm{day}^{-1}\right)$} & \multirow{2}{*}{$\mathrm{SEM}^{2}$} & \multicolumn{2}{|c|}{ P-value } \\
\hline & 1.5 & 3.0 & 4.5 & 6.0 & & Linear & Quadratic \\
\hline TDMI, kg day ${ }^{-1}$ & 10.35 & 10.47 & 7.93 & 8.67 & 1.00 & 0.0546 & 0.680 \\
\hline TDMI, \% BW & 1.99 & 2.04 & 1.52 & 1.69 & 0.20 & 0.072 & 0.695 \\
\hline HDMI, kg day ${ }^{-1}$ & 9.05 & 8.06 & 4.98 & 5.72 & 1.05 & 0.010 & 0.303 \\
\hline CI, kg day ${ }^{-1}$ & 1.30 & 2.42 & 2.94 & 2.95 & 0.25 & $<0.001$ & 0.022 \\
\hline \multicolumn{8}{|c|}{ Intake of nutritional components } \\
\hline $\mathrm{OM}, \mathrm{kg}$ day $^{-1}$ & 9.43 & 9.43 & 7.02 & 7.70 & 0.93 & 0.043 & 0.624 \\
\hline $\mathrm{CP}, \mathrm{kg}_{\mathrm{day}}{ }^{-1}$ & 1.72 & 1.86 & 1.47 & 1.55 & 0.17 & 0.160 & 0.838 \\
\hline EE, $\mathrm{kg} \mathrm{day}^{-1}$ & 0.45 & 0.44 & 0.34 & 0.35 & 0.06 & 0.056 & 0.765 \\
\hline NDF, kg day ${ }^{-1}$ & 6.33 & 5.67 & 3.82 & 4.30 & 0.69 & 0.012 & 0.284 \\
\hline NDF, \% BW & 1.21 & 1.10 & 0.72 & 0.83 & 0.13 & 0.012 & 0.293 \\
\hline NFC, kg day ${ }^{-1}$ & 1.69 & 2.17 & 1.92 & 2.07 & 0.23 & 0.252 & 0.362 \\
\hline TDN, kg day ${ }^{-1}$ & 7.48 & 7.30 & 5.60 & 5.98 & 0.84 & 0.060 & 0.662 \\
\hline
\end{tabular}

${ }^{1} \mathrm{TDMI}=$ total dry matter intake, $\mathrm{BW}=$ body weight, $\mathrm{HDMI}=$ herbage dry matter intake, $\mathrm{CI}=$ concentrate intake, $\mathrm{OM}=$ organic matter, $\mathrm{CP}=$ crude protein, $\mathrm{EE}=$ ether extract, $\mathrm{NDF}=$ neutral detergent insoluble fiber, $\mathrm{NFC}=$ non-fibrous carbohydrates, $\mathrm{TDN}=$ total digestible nutrients. ${ }^{2}$ SEM: standard error of the mean.

The increasing levels of concentrate supplied to grazing cows did not affect $(\mathrm{P}>0.05)$ their total dry matter intake (TDMI), which averaged 9.24 $\mathrm{kg}$ day $^{-1}$ and $1.79 \%$ body weight day ${ }^{-1}$ (Table 4). However, herbage dry matter intake (HDMI) decreased $(\mathrm{P}<0.05)$, which demonstrates the substitution effect (MOORE, 1980). There was a substitution rate of $2.23 \mathrm{~kg} \mathrm{day}^{-1}$ of herbage for each kilogram of concentrate consumed. Similarly, Lima et al. (2001) observed a substitution rate of 1.06 for animals on pasture. In the study conducted by Bargo et al. (2003), the authors observed a $13 \%$ decrease in HDMI in animals supplemented with 1.8 to $10.4 \mathrm{~kg}$ concentrate $\mathrm{DM}$ day $^{-1}$ in relation to control treatment.

The decrease in HDMI stemming from the greater concentrate intake led to a reduction of NDF intake in $\mathrm{kg} \mathrm{day}^{-1}$ and in $\% \mathrm{BW}$ day $^{-1}$, which decreased by $1.37 \mathrm{~kg}$ day $^{-1}$ and $0.26 \%$ day $^{-1}$, respectively, with each kilogram of concentrate consumed. Silva et al. (2009) observed an NDF intake of $1.57 \%$ of body weight day ${ }^{-1}$. Neutral detergent fiber intake is important for ruminants, since it maintains adequate rumen function. However, according to Mertens (1987), a maximum NDF intake of $1.20 \% \mathrm{BW}$ day $^{-1}$ is recommended so that dry matter intake is not limited due to rumen fill. Thus, the NDF intake observed in this study might be limiting the dry matter intake of the animals due to the effects of the lower passage rate of particles resulting from the longer time the feed remains in the rumen.

The reduction in the intakes of $\mathrm{OM}$ and TDN $(\mathrm{P}<0.05)$ with the higher supplementation levels may be related to the decrease in HDMI (Table 4) as 
a consequence of the elevated nutritional quality of the grazed grass (Table 2).

There was no effect $(\mathrm{P}>0.05)$ on the apparent digestibility of DM with the increase in concentrate intake. An increase in the digestibility coefficient of this nutrient was expected, given the higher supply of nitrogen to the cellulolytic rumen microorganisms, resulting in improved degradation of the dietary polymers in the rumen (VAN SOEST, 1994). Providing 0, 1, 3, and $5 \mathrm{~kg}$ of concentrate day $^{-1}$ to dairy cows, Silva et al. (2009) observed
DM digestibility coefficients of $54.6,54.5,57.5$, and 59.8, which are lower values than those found in the current study.

The reduction $(\mathrm{P}<0.05)$ of the digestibility coefficient of NDF with the higher concentrate intake may be due to the lower NDF intake caused by the decrease in HDMI and the increase in concentrate intake (Table 5). This decrease in digestibility may be related to the greater growth of amylolytic microorganisms and competition with cellulolytic microorganisms (MERTENS, 1994).

Table 5. Apparent digestibility coefficients of dry matter and nutrients according to supplementation level.

\begin{tabular}{|c|c|c|c|c|c|c|c|}
\hline \multirow{2}{*}{ Item $^{1}$} & \multicolumn{4}{|c|}{ Supplementation level $\left(\mathrm{kg} \mathrm{day}^{-1}\right)$} & \multirow{2}{*}{$\mathrm{SEM}^{2}$} & \multicolumn{2}{|c|}{ P-value } \\
\hline & 1.5 & 3.0 & 4.5 & 6.0 & & Linear & Quadratic \\
\hline $\mathrm{DM}$ & 65.84 & 66.15 & 67.73 & 65.31 & 2.58 & 0.999 & 0.164 \\
\hline $\mathrm{OM}$ & 68.85 & 68.46 & 69.49 & 67.33 & 2.51 & 0.416 & 0.365 \\
\hline $\mathrm{CP}$ & 75.44 & 73.48 & 77.25 & 74.35 & 2.47 & 0.895 & 0.590 \\
\hline $\mathrm{EE}$ & 75.16 & 81.80 & 80.19 & 76.67 & 4.26 & 0.859 & 0.196 \\
\hline NDF & 75.87 & 74.03 & 68.61 & 69.80 & 2.38 & 0.031 & 0.434 \\
\hline NFC & 33.27 & 47.06 & 63.22 & 54.76 & 6.58 & 0.001 & 0.015 \\
\hline
\end{tabular}

${ }^{1} \mathrm{DM}=$ dry matter $\mathrm{OM}=$ organic matter, $\mathrm{CP}=$ crude protein, $\mathrm{EE}=$ ether extract, $\mathrm{NDF}=$ neutral detergent insoluble fiber, $\mathrm{NFC}=$ non-fibrous carbohydrates. ${ }^{2}$ SEM: standard error of the mean.

In the present study, the observed NDF digestibility was above the average $63.80 \%$ reported by Goularte et al. (2011), who increased the concentrate content $(30,40,50$, and $60 \%)$ in the diet of non-lactating dairy cows in the feedlot receiving corn silage, and 49.31\% cited by Bürger et al. (2000), who increased the dietary concentrate content (30, $45,60,75$, and $90 \%$ ) of feedlot Holstein calves fed coast-cross grass hay. Despite this discrepancy in NDF digestibility values observed in the present study and some described in the literature, and considering the very high values obtained here, it should be stressed that the Tanzania grass used had an elevated nutritional value (Table 2), and its supply allowed great selectivity by the animals, unlike studies cited previously. In these studies, researchers used confined animals subjected to total diets, in which roughage and concentrate are mixed, thereby reducing selectivity by the animal.
The increase observed in the apparent digestibility coefficient of NFC may be attributed to their increased intake, which reduces the proportion of endogenous excretion of these nutrients (VAN SOEST, 1967). However, this researcher reported that the NFC have an almost complete digestibility in the gastrointestinal tract of ruminants - of $98 \%$, on average. Cabral et al. (2006) worked with rumenfistulated cattle receiving diets with $90 \%$ roughage (corn silage, elephant grass silage, or Tifton 85 grass hay) and found an apparent NFC digestibility of $85.58,65.96$, and $41.86 \%$, for these roughage feeds, respectively. However, when they estimated the true digestibility by subtracting the metabolic excretion of NFC from the NFC found in the feces, they found an average true digestion of $96.6 \%$.

The day-time and total rumination times increased linearly $(\mathrm{P}<0.05)$, by approximately 3.72 and $2.48 \%$ for each kilogram of concentrate 
consumed, respectively, while the duration of daytime grazing decreased $(\mathrm{P}<0.05)$ by $3.99 \%$ for each kilogram of concentrate consumed (Table 6). This increase in the time expended on the rumination activity may be related to the lower HDMI and trends $(\mathrm{P}=0.078 ; \mathrm{P}=0.059)$ towards a reduction of the time expended on the day-time and total grazing activity, respectively, considering that the activities are mutually exclusionary.

Table 6. Feeding behavior according to supplementation level.

\begin{tabular}{|c|c|c|c|c|c|c|c|}
\hline \multirow{2}{*}{ Item } & \multicolumn{4}{|c|}{ Supplementation level $\left(\mathrm{kg} \mathrm{day}^{-1}\right)$} & \multirow{2}{*}{ SEM $^{1}$} & \multicolumn{2}{|c|}{ P-value } \\
\hline & 1.5 & 3.0 & 4.5 & 6.0 & & Linear & Quadratic \\
\hline Day-time idleness, \% & 32.02 & 34.65 & 36.84 & 28.07 & 5.95 & 0.497 & 0.105 \\
\hline Night-time idleness, \% & 49.65 & 44.79 & 49.65 & 48.27 & 3.49 & 0.919 & 0.279 \\
\hline Total idleness, $\%$ & 41.86 & 40.31 & 43.99 & 39.34 & 3.63 & 0.653 & 0.430 \\
\hline Day-time rumination, \% & 22.81 & 23.68 & 25.88 & 32.02 & 3.84 & 0.027 & 0.295 \\
\hline Night-time rumination, $\%$ & 34.03 & 38.19 & 35.76 & 37.15 & 3.05 & 0.409 & 0.457 \\
\hline Total rumination, $\%$ & 29.07 & 31.78 & 31.39 & 34.88 & 2.96 & 0.030 & 0.782 \\
\hline Day-time grazing, \% & 45.18 & 41.67 & 37.28 & 39.91 & 4.24 & 0.078 & 0.198 \\
\hline Night-time grazing, $\%$ & 16.32 & 17.01 & 14.58 & 14.58 & 1.59 & 0.209 & 0.784 \\
\hline Total grazing, $\%$ & 29.07 & 27.91 & 24.61 & 25.77 & 2.36 & 0.059 & 0.395 \\
\hline
\end{tabular}

${ }^{1}$ SEM: standard error of the mean.

No effects of supplementation levels $(\mathrm{P}>0.05)$ were observed on the rumen $\mathrm{pH}$ values, which averaged $6.24 \pm 0.19$ (Table 7). This may be related to the observed concentrate intake, which was below the value considered ideal for this study. The rumen $\mathrm{pH}$ is known to be influenced by concentrate intake levels, collection time after feeding, rate of
VFA absorption by the rumen epithelium, nature of the diet, and saliva production (GONZÁLEZ et al., 2012). However, according to Bargo et al. (2002), a significant decrease in the rumen $\mathrm{pH}$ of dairy cows on pasture, supplemented with concentrate, occurs when more than $8 \mathrm{~kg}$ day $^{-1}$ of concentrate DM are provided.

Table 7. Rumen $\mathrm{pH}$ and rumen ammonia nitrogen (RAN) concentration according to supplementation level.

\begin{tabular}{lccccccccc}
\hline \multirow{2}{*}{ Item } & \multicolumn{3}{c}{ Supplementation level $\left(\mathrm{kg} \mathrm{day}^{-1}\right)$} & \multirow{2}{*}{ SEM $^{1}$} & \multicolumn{3}{c}{ P-value } \\
\cline { 2 - 4 } & 1.5 & 3.0 & 4.5 & 6.0 & & Sup $^{2}$ & Time & Sup $\times$ Time $^{3}$ \\
\hline pH & 6.26 & 6.32 & 6.17 & 6.22 & 0.19 & 0.599 & 0.660 & 0.965 \\
RAN $\left(\mathrm{mg} \mathrm{dL}^{-1}\right)$ & 11.99 & 14.60 & 16.03 & 18.75 & 1.72 & 0.006 & 0.006 & 0.978 \\
\hline
\end{tabular}

${ }^{1}$ SEM: standard error of the mean, ${ }^{2}$ Sup: supplementation, ${ }^{3}$ Sup $\times$ Time: effect of the interaction between supplementation levels and collection times.

Supplementation of dairy cows on pasture is an efficient technique to increase animal production; however, a decline in the rumen $\mathrm{pH}$ may reduce the fiber digestibility. Ørskov (1986) stated that the rumen $\mathrm{pH}$ decreases after concentrate feeds are consumed, due to their rapid fermentation. Mertens (1992) stressed that the fiber digestion declines when the rumen $\mathrm{pH}$ is below 6.7, which occurred in this study. Thus, $\mathrm{pH}$ values below those cited by Mertens (1992) were observed, which likely reduced the NDF digestibility observed in this study.

The higher concentrations of $\operatorname{RAN}(\mathrm{P}<0.05$; linear effect) with the increasing supplementation levels are related to the increased concentrate intake 
and the increasing proportion of rumen protein originating from the concentrate, which has a faster degradation in relation to the protein from the herbage (Table 7). The RAN is known to originate from the dietary non-protein nitrogen, degradation of the dietary true protein, and recycling via saliva or diffusion through the rumen wall, as well as through the proteolysis of microbial protein caused by autolysis or predation by protozoa (VAN SOEST, 1994).

Leng (1990) and Detmann et al. (2010) reported values between 8 and $10 \mathrm{mg} \mathrm{dL}^{-1}$ RAN to optimize the rumen digestion of the fiber from the herbage, and 15 to $20 \mathrm{mg} \mathrm{dL}^{-1}$ for optimal voluntary intake by cattle under tropical conditions. In this way, considering that fibrolytic microorganism use the ruminal $\mathrm{N}-\mathrm{NH}_{3}$ as the main nitrogen precursor for protein synthesis and growth (RUSSELL, 2002), concentrate intakes higher than $2.9 \mathrm{~kg} \mathrm{day}^{-1}$ allow for an adequate rumen digestion and maximization of intake in grazing animals.

\section{Conclusions}

Increasing the supply of concentrate to dairy cows on pasture reduces their herbage intake without compromising total dry matter intake or changing rumen-fluid $\mathrm{pH}$ values.

\section{References}

ASSOCIATION OF OFFICIAL ANALYTICAL CHEMISTIS - AOAC. Official methods of analysis. $13^{\text {th }}$ ed. Arlington: AOAC International, 1990. 989 p.

BARBOSA, M. A. F.; NASCIMENTO JÚNIOR, D.; CECATO, U. Dinâmica da pastagem e desempenho de novilhos em pastagem de capim Tanzânia sob diferentes ofertas de forragem. Revista Brasileira de Zootecnia, Viçosa, MG, v. 35, n. 4, p. 1594-1600, 2006.

BARGO, F.; MULlER, L. D.; DELAHOY, J. E.; CASSIDY, T. W. Milk response to concentrate supplementation of high producing dairy cows grazing at two pasture allowances. Journal of Dairy Science, Champaign, v. 85, n. 7, p. 1777-1792, 2002.
BARGO, J.; MULleR, L. D.; KOLVER, E. S.; DELAHOY, J. E. Invited review: production and digestion of supplemented dairy cows on pasture. Journal of Dairy Science, Champaign, v. 86, n. 1, p. 1-42, 2003.

BÜRGER, P. J.; PEREIRA, J. C.; SILVA, J. F. C.; VALADARES FILHO, S. C.; QUEIROZ, A. C.; CECON, P. R.; MONTEIRO, H. C. F. Consumo e digestibilidade aparente total e parcial em bezerros holandeses alimentados com dietas contendo diferentes níveis de concentrado. Revista Brasileira de Zootecnia, Viçosa, MG, v. 29, n. 1, p. 206-214, 2000.

CABRAL, L. S.; VALADARES FILHO, S. C.; DETMANN,E.; MALAFAIA,P.A.M.;ZERVOUDAKIS, J. T.; SOUZA, A. L.; VELOSO, R. G.; NUNES, P. M. M. Consumo e digestibilidade dos nutrientes em bovinos alimentados com dietas à base de volumosos tropicais. Revista Brasileira de Zootecnia, Viçosa, MG, v. 35, n. 6, p. 2406-2412, 2006.

CARneVAlli, R. A.; SILVA, S. C.; BUENO, A. A. O.; UEBELE, M. C.; BUENO, F. O.; HODGSON, J.; SILVA, G. N.; MORAIS, J. P. G. Herbage production and grazing losses in Panicum maximum cv. Mombaça under four grazing managements. Tropical Grasslands, Brisbane, v. 40, n. 3, p. 165-176, 2006.

DETMANN, E.; PAULINO, M. F.; VALADARES FILHO, S. C. Otimização do uso de recursos forrageiros basais. In: SIMPÓSIO DE PRODUÇÃO DE GADO DE CORTE, 7., 2010, Viçosa, MG. Anais... Viçosa, MG: DZO-UFV, 2010. p. 191-240.

DETMANN, E.; PAULINO, M. F.; ZERVOUDAKIS, J. T.; VALADARES FILHO, S. C.; EUCLYDES, R. F.; LANA, R. P.; QUEIROZ, D. S. Cromo e indicadores internos na determinação do consumo de novilhos mestiços, suplementados, a pasto. Revista Brasileira de Zootecnia, Viçosa, MG, v. 30, n. 5, p. 1600-1609, 2001.

DIFANTE, G. S.; EUCLIDES, V. P. B.; NASCIMENTO JÚNIOR, D.; SILVA, S. C.; BARBOSA, R. A.; TORRES JÚNIOR, R. A. A. Desempenho e conversão alimentar de novilhos de corte em capim-Tanzânia submetido a duas intensidades de pastejo sob lotação rotativa. Revista Brasileira de Zootecnia, Viçosa, MG, v. 39, n. 1, p. 3341, 2010.

GONZÁLEZ, L.A.; MANTECAB, X.; CALSAMIGLIA, S.; SCHWARTZKOPF-GENSWEINC, K. S.; FERRET, A. Ruminal acidosis in feedlot cattle: Interplay between feed ingredients, rumen function and feeding behavior (a review). Animal Feed Science and Technology, Amsterdam, v. 172, n. 1-2, p. 66-79, 2012. 
GOUlARTE, S. R.; ÍTAVO, L. C. V.; ÍTAVO, C. C. B. F.; DIAS, A. M.; MORAIS, M. G.; SANTOS, G. T.; OLIVEIRA, L. C. S. Comportamento ingestivo e digestibilidade de nutrientes em vacas submetidas a diferentes níveis de concentrado. Arquivo Brasileiro de Medicina Veterinária e Zootecnia, Belo Horizonte, v. 63, n. 2, p. 414-422, 2011.

HALL, M. B. Calculation of non-structural carbohydrate content of feeds that contain non-protein nitrogen. Florida: University of Florida, 2000. A-25 p. (Bulletin, 339).

LENG, R. A. Factors affecting the utilization of poorquality forages by ruminants particularly under tropical conditions. Nutrition Research Reviews, Belfast, v. 3, n. 1, p. 277-303, 1990.

LIMA, M. L. P.; BERCHIELLI, T. T.; NOGUEIRA, J. R.; RUGGIERI, A. C.; AROEIRA, L. J. M.; SALMAN, A. K. D.; SOARES, J. P. G. Estimativa do consumo voluntário do capim-Tanzânia (Panicum maximum, Jacq. cv. Tanzânia) por vacas em lactação sob pastejo rotacionado. Revista Brasileira de Zootecnia, Viçosa, MG, v. 30, n. 6, p. 1919-1924, 2001.

MERTENS, D. R. Análise da fibra e sua utilização na avaliação de alimentos e formulação de rações. In: SIMPÓSIO INTERNACIONAL DE RUMINANTES, REUNIÃO ANUAL DA SOCIEDADE BRASILEIRA DE ZOOTECNIA, 29., 1992, Lavras. Anais... Lavras: SBZ, 1992. p. 188-219.

Predicting intake and digestibility using mathematical models of ruminal function. Journal of Dairy Science, Champaign, v. 64, n. 5, p. 1548-1558, 1987.

Regulation of forage intake. In: FAHEY JÚNIOR, G. C. (Ed.). Forage quality evaluation and utilization. Madison: American Society of Agronomy, 1994. p. 450-493.

MOORE, J. E. Forage crops. In: HOVELAND, C. S. (Ed.). Crop quality, storage, and utilization. Madison: Crop Science Society of America, 1980. p. 61-91.

NATIONAL RESEARCH COUNCIL - NRC. Nutrient requirements of dairy cattle. $7^{\text {th }}$ ed. Washington: National Academy Press, 2001. 408 p.
ØRSKOV, E. R. Starch digestion and utilization in ruminants. Journal of Dairy Science, Champaign, v. 63, n. 5, p. 1624-1633, 1986.

RUSSEL, J. B. Rumen microbiology and its role in ruminant nutrition. Ithaca: Cornell University Press, 2002. $121 \mathrm{p}$.

SANTOS, F. A. P.; MARTINEZ, J. C.; VOLTOLINI, T. V.; NUSSIO, C. M. B. Utilização da suplementação com concentrado para vacas em lactação mantidas em pastagens tropicais. In: SIMPÓSIO GOIANO SOBRE MANEJO E NUTRIÇÃO DE BOVINOS DE CORTE E LEITE, 5., 2003, Goiânia. Anais... Goiânia: CBNA, 2003. p. 289-346.

SILVA, C. V.; LANA, R. P.; CAMPOS, J. M. S.; QUEIROZ, A. C.; LEÃO, M. I.; ABREU, D. C. Consumo, digestibilidade aparente dos nutrientes e desempenho de vacas leiteiras em pastejo com dietas com diversos níveis de concentrado e proteína bruta. Revista Brasileira de Zootecnia, Viçosa, MG, v. 38, n. 7, p. 1372-1380, 2009.

STATISTICAL ANALYSIS SYSTEM INSTITUTE SAS Institute. Sas user's guide: statistics, Version 9.3. Cary: Statistical Analysis System Institute, 2011. 1093 p.

VAN SOEST, P. J. Development of a comprehensive system of feed analysis and its application to forages. Journal of Dairy Science, Champaign, v. 26, n. 1, p. 119128, 1967.

Nutritional ecology of the ruminant. $2^{\text {th }}$ ed. Ithaca: Cornell University Press, 1994. 476 p.

VAN SOEST, P. J.; ROBERTSON, J. B.; LEWIS, B. A. Methods for dietary fiber, neutral detergent fiber, and nonstarch polysaccharides in relation to animal nutrition. Journal of Dairy Science, Champaign, v. 74, n. 10, p. 3583-3597, 1991.

ZANINE, A. M.; NASCIMENTO JÚNIOR, D.; SANTOS, M. E. R.; PENA, K. S.; SILVA, S. C.; SBRISSIA, A. F. Características estruturais e acúmulo de forragem em capim-Tanzânia sob pastejo rotativo. Revista Brasileira de Zootecnia, Viçosa, MG, v. 40, n. 11, p. 2364-2373, 2011. 